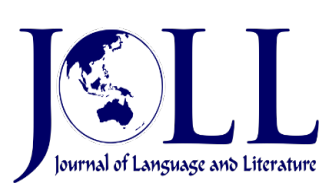

Vol. 21 No. 1, April 2021, pp. $35-47$

DOI: 10.24071/joll.v21i1.2961

Available at https://e-journal.usd.ac.id/index.php/JOLL/index

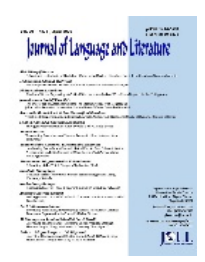

This work is licensed under a Creative Commons Attribution-ShareAlike 4.0 International License.

\title{
The Causative in Indonesian
}

\author{
Benedictus Bherman Dwijatmoko \\ dwijatmoko@usd.ac.id \\ Graduate Program in English Language Studies, Universitas Sanata Dharma, INDONESIA
}

\begin{abstract}
In the Principle and Parameter approach, the Indonesian suffix -kan can be treated as an inflection that functions to create a causative relation between the arguments which the verb takes. Along with the treatment, the voice affixes (Vc) meng-, di-, and ter- also heads a phrase, a Voice Phrase (VcP), and a verbal sentence in Indonesian, which really has the status of a Complementizer Phrase (CP), has a VCP as its main element. Vc may take a VP or any other phrase category including a Causative Phrase (CsP) headed by the suffix -kan as its complement. A CsP can also become the complement or adjunct or a VP or another category phrase which becomes the complement of a VcP. The analysis of the suffix - kan as an inflection can explain the similarity of the pairs of sentences which are syntactically similar and have the same meaning, solve the problem of meaning which usually accompanies the discussion of the suffix, and explain the production of Indonesian sentences which contain the suffix -kan. Furthermore, the study may also provide insights for English and Indonesian course designers to develop materials which can present the topic clearly and for Indonesian and English translators to arrive at a good translation equivalent.
\end{abstract}

Article

information

Keywords: transformation grammar; causative phrase; suffix -kan, causative relation; complement; adjunct

\section{Introduction}

Indonesian is very rich in the use of the suffix -kan to show its numerous meanings. The various uses of the suffix may pose significant problems to Indonesian learners who are learning English and use English in the communication as well as English speakers to communicate in Indonesian. A thorough discussion of the suffix may provide insights to both English and Indonesian course designers to develop learning materials for English and Indonesian students. It may also provide insights to translators to translation Indonesian sentences which uses a -kan verb in the predicate.

The suffix -kan in Indonesian is often analyzed as a derivational affix which functions to form new words. The suffix may form a new verb from another category or a new verb from another verb. The verbs 
mengencangkan 'to tighten' and menguangkan 'to cash' are said to be formed from the adjective kencang 'tight' and the noun uang 'money' respectively with the suffix -kan in combination with the active voice prefix meng. The verb membelikan 'to buy something for somebody' and mengambilkan 'to get something for somebody' are said to be formed from membeli 'to buy something' and mengambil 'to get something' with the suffix.

The analysis, however, fails to capture the syntactic similarity between the pairs of sentences (1) and (2) and (3) and (4).

(1) Susan tidur.

Susan $\theta$-sleep

'Susan slept.'

(2) Ibu menidurkan Susan.

Mom act-sleep-Cs Susan

'Mom lullabied Susan.'

(3) Ibu membeli boneka.

Mom act-buy doll

'Mom bought a doll.'

(4) Ibu membelikan Susan boneka. Mom act-buy-Cs Susan doll

'Mom bought Sudan a doll.'

Sentences (1) and (2) are similar in that the meaning of (1) is contained in (2), and sentence (3) is similar to sentence (4) in that the action which Mom did in (3) is contained in (4). The similarity which exists between the sentences in each pair only lies in the verb stem tidur 'sleep' in (1) and (2), and in the verb stem beli 'buy', the subject ibu 'mom', and the direct object boneka 'doll in (3) and (4). The verb in (2) is formed by adding the active prefix (act) and the suffix -kan to the verb tidur 'sleep', and the verb in (4) is formed by adding the suffix -kan to the verb membeli 'buy.'

The suffix -kan occurs in various contexts. Son \& Cole (2008) identify four different constructions with -kan. The suffix can occur with adjectives and inchoative verbs, with benefactives, as with an NP as the goal of a preposition, and with ditransitive verbs. In all occurrences of -kan, Sneddon (1996) identifies two basic functions, namely to mark an object as patient and to mark an object as a beneficiary.

The different contexts also show different meanings. Moeliono \& Dardjowidjojo (1988) identify four major meanings of -kan: (i) expressing an action which the stem shows like in melakukan 'to do' and membicarakan 'to discuss', (ii) causing something or somebody to become like what the stem shows like in membebaskan 'to free' which is derived from bebas 'free' and menghabiskan 'to finish' which is derived from habis 'finish', (iii) putting something or somebody in a location as expressed by the stem like in merumahkan 'to put somebody into a house or to dischage' which is derived from rumah 'house', and memenjarakan 'to put somebody into a jail or to jail' which is derived from penjara 'jail', and (iv) doing something for somebody else like in membelikan 'to buy something for somebody' and menjualkan 'to sell something for somebody'.

The various functions and meanings which -kan have is the result of the analysis which treats the suffix as a derivational suffix. The analyses above and also the analysis which Kaswanti Purwo (1995 \& 1997) give, however, cannot explain the presence of the various meanings.

The analysis of the suffix $-k a n$ as an inflection can solve the problems which the analysis of the suffix as a derivation fails to solve. In the Principle and Parameter approach, the suffix -kan becomes the head of a causative phrase or a CsP. The analysis can show the syntactic similarity of sentences like in (1) - (4) and explain how the core meaning of $\mathrm{Cs}$, that is 'causative', can be identified in various sentence patterns.

The Principle and Parameter (PP) approach as discussed in Chomsky (1981), Radford (1988), Haegeman (1991), Haegeman and Gueron (1999), and Dwijatmoko (2002; 2020) was used instead of the newer approach in transformational grammar (Chomsky 1995, Seuren 2004, Radford 2004). In the PP approach, a sentence is analyzed as a complementizer phrase (CP) which takes an inflection phrase (IP) as its complement, which in turn takes a verb phrase (VP). Different from their theory, however, the subject of a sentence is not generated as the specifier of $I$. Following Haegeman and Guéron (1999) and Zagona (2002), a sentence subject is generated 
as the specifier of $\mathrm{V}$.

\section{Methodology}

The object of the study on the Indonesian suffix -kan in this paper is Indonesian sentences which has the suffix in the predicate verb. The sentences studied are generated from the internal (I-) language (Chomksy, 1981) of the researcher. I-language is the language which exists in the mind of the speaker, and sentences in I-language are present in their $d($ eep)-structures. A dstructure is the configuration of elements which a head requires and is converted into the s(urface)-structure to meet the morphological and syntactic rules with the application of some transformation (T-) rules. (Chomsky, 1981; Radford,1988; Haegeman,1991; Haegeman \& Gueron, 1999).

The formation of d-structure and $s$ structure follows the X-bar theory (Chomsky, 1981; Radford,1988; Haegeman,1991; Haegeman \& Gueron, 1999). In the X-bar theory, (i) a phrase of any category (XP) branches into another phrase which functions as a specifier and $X^{\prime}$ or the the intermediate level of X, (ii) X' branches to another $\mathrm{X}^{\prime}$ and another phrase as an adjunct which comes after the head or an attribute which comes before the head, and finally (iii) $\mathrm{X}^{\prime}$ branches to $X$ as the head and another phrase as its complement. Adjunction and attribution processes are recurrent.

The data used for the analysis in this paper are sentences which contain the suffix kan in its various functions and meanings. The $\mathrm{d}$-structures of the sentences in I-language are, then, identified, and the rules which form the $\mathrm{d}$-structures are explained.

To justify the correctness of the rules and theories in this paper the principle of acceptability is used. A rule or theory is good or correct if and only if it produces an acceptable sentence, and any rule or theory which produces an unacceptable sentence is refuted.

To present the d-structure of a sentence, brackets will be used. The d-structure of the phrase XP, the configureation below is used.
The d-structure reads '(i) the phrase XP branches into $\mathrm{YP}_{1}$ as the specifier amd $\mathrm{X}^{\prime}$, (ii) $\mathrm{X}^{\prime}$ branches into another $\mathrm{X}^{\prime}$ and $\mathrm{YP}_{2}$ as the adjunct, (iii) $\mathrm{X}^{\prime}$ then branches into $\mathrm{YP}_{3}$ as the attribute and another $X^{\prime}$, and finally (iv) $X^{\prime}$ branches into $\mathrm{X}$ as the head and $\mathrm{YP}_{4}$ as the complement.

To ease the discussion, the sentences are numbered in parenthesis consecutively from the introduction to the discussion. Thus, the sentences are sometimes only referred with their number.

\section{Results and Discussion}

The discussion in this paper falls into two major parts namely the need of a Causative Phrase (CsP) and functions of the CsP.

\section{The Need of CsP}

Along with the analysis of the suffix -kan as an inflection, the Indonesian voice affixes are also analyzed as inflections and head voice (Vc) phrases. A Vc may take a verb phrase (VP), a noun phrase (NP), an adjective phrase (AP), a prepositional phrase (PP), or a phrase headed by a relational suffix -kan, $-i$, or - per as its complement. Due to the limited space, the nature of $\mathrm{Vc}$ as an inflection will not be discussed here.

The status of Cs as an inflection which heads a phrase can be seen in sentences like (6) and (7).

$\begin{array}{lll}\text { (6) Ibu menidurkan Susan. } & \text { Susan } \\ & \text { Mom act-sleep-Cs labied Susan. } \\ \text { 'Mom lullabien } & \\ \text { (7) Susan tidur. } & \\ & \text { Susan Ø-sleep } \\ & \text { Susan slept.' }\end{array}$

Sentence (6) is different from (7) in that (6) contains a phonologically realized Vc, Cs, and the NP $i b u$ and whereas (7) does not. The presence of Cs in (6) also enables the presence of the NP $i b u$. The NP $i b u$ does not come from inside the VcP for a Vc does not require any argument (NP). Study (8) and (9) below. 
(8a) Ibu membeli kue.

Mom act-buy cake

'Mom bought a cake.'

(8b) meng- [vp ibu beli kue]

(9a) Rita membaca surat dari

Rita act-read letter from

temannya.

friend her

'Rita read a letter from her friend.'

(9b) meng- [vp Rita baca surat dari temannya]

In (8) and (9), it can be seen that Vc does not take a specifier. Vc takes the VP [vp ibu beli kue] 'mom buy a cake' in (8) and [vp Rita baca surat dari temannya] 'Rita read a letter from her friend' in (9). In (8) kue 'a cake is the complement of beli, and ibu 'mom' is the specifier. In (9) surat dari temannya 'a letter from her friend' is the complement of baca 'read', and Rita is the specifier. In both (8) and (9), Vc does not take a specifier. Returning to (2), if the NP ibu is not a specifier of Vc and is not an element of the VP [Susan tidur] 'Susan sleep', then $i b u$ is the specifier of Cs. The structure of (2) is therefore like the following.

(10) $\left[\mathrm{vcP}^{-}-\left[\mathrm{vc}^{\prime}\right.\right.$ meng- $[\mathrm{csP}$ ibu [Cs' $-\mathrm{kan}[\mathrm{vp}$ Susan tidur]]]]]

CsP is the complement of Vc. Cs takes the VP [Susan tidur] as its complement and the NP $i b u$ 'mom' as its specifier.

Structure (10) is the d-structure of (2) or the configuration which all the heads in the sentence require. The d-structure then undergoes some transformations to satisfy some morphological and syntactic requirements of Indonesian and form the sstructure. The transformations, however, will not be discussed in this paper.

The ability of Cs to take an NP can be supported further with sentences like (11) and (13).

Hardi act-make Cs I coffee
'Hardi made me coffee'
Hardi membuat kopi.
Hardi act-make coffee
'Hardi made coffee.'

Sentences (11) is different from (12) in the presence of Cs and the NP Rita. Similarly, sentence (13) is different from (14) in the presence of Cs and the NP me. It can be said, therefore, that the presence of Cs in (11) and (13) enables the occurrence of Rita and me respectively, or that Rita in (11) and me in (13) are an element of a phrase which Cs heads.

\section{The Functions of CsP}

As a phrase, a CsP can become the complement of a Vc, the complement of a lexical item, and an adjunct of a lexical item. The various meanings which Cs may show, which Alwi, et. al (2000) give, is due to the function of the CsP.

\section{Complement of $\mathrm{Vc}$}

A CsP can become the complement of a Vc. In (15) and (16) below, CsP becomes the complement of Vc.

(15a) Ronny menghabiskan uangnya. Ronny act-finish Cs money his 'Ronny used up all his money.'

(15b) $\left[\mathrm{vcP}^{-}-\left[\mathrm{vc}^{\prime}\right.\right.$ meng- $\left[\mathrm{csp}\right.$ Ronny [ $\mathrm{Cs}^{\prime}-\mathrm{kan}[\mathrm{vP}$ uangnya habis]]]]]

(16a) Mereka merobohkan rumah-rumah itu.

they act-fall Cs house house the

'They pulled down all the houses.'

(16b) [vcp - [vc' meng- [csp mereka [cs'-kan [vp rumah-rumah itu roboh]]]]]

In (15), Cs takes the NP Ronny as the specifier and the VP [uangnya habis] 'his money - to finish' as its complement. In (16), Cs takes the NP mereka 'they' as the specifier and the VP [rumah-rumah itu roboh] 'the houses - fall down' as its complement.

The characteristics of Indonesian verbs which can become the complement of a CsP which becomes the complement of a Vc can be identified. The verbs habis 'finish' and roboh 
'fall down' occur with a zero form of Vc. They have the feature of [+zero form of Vc]. Study these sentences.

(17a) Uangnya habis untuk judi. money his finish for gamble 'All his money was used up for gambling.'

(17b) $\left[\mathrm{vcP}-\left[\mathrm{vc}^{\prime} \Theta-\right.\right.$ [vp uangnya habis untuk judi]]]

(18a) Rumah itu roboh kemarin. house the fall down yesterday 'The houses fell down yesterday.'

(18b) $\left[\mathrm{vcP}_{\mathrm{cP}}-\left[\mathrm{vc}_{\mathrm{c}} \Theta-\right.\right.$ - [vp rumah itu roboh kemarin]]]

The verbs habis 'finish' and roboh 'fall down' do not semantically select or s-select a complemet or have the feature [-complement]. In a VP, they only s-select a specifier. In (17) habis 'finish' occurs with uangnya 'his money' as the specifier and untukjudi 'for gambling' as an adjunct. In (18), the verb roboh 'fall down' occurs with rumah-rumah itu 'the houses' as the specifier and kemarin 'yesterday' as an adjunct.

All verbs which have the features [+zero form of Vc, -complement] head a VP which can become the complement of $\mathrm{Cs}$ in a sentence. Of the 58 verbs with a [+zero form of $\mathrm{Vc}$ ] in the list verbs have the feature of [-complement] (Moeliono \& Darwjowidjojo, 1998), 11 verbs have the feature of [+complement]. As presented in Table 1, thirty four of the verbs with [-complement] can occur as the head of a VP which can become the complement of Cs, and 13 verbs cannot occur with Cs.

Table 1

The Occurrence of Bare Verbs with CsP

\begin{tabular}{|c|c|c|}
\hline & [+COMPLEMENT] & [-COMPLEMENT] \\
\hline [+CAUSATIVE] & $\begin{array}{l}\text { ikut 'follow', ingat 'remember', } \\
\text { ingin 'want', jadi 'become', } \\
\text { kenal 'be aquanted', lupa } \\
\text { 'forget', minta 'ask', minum } \\
\text { 'drink', mohon 'request', } \\
\text { percaya 'believe', tunduk 'obey' }\end{array}$ & $\begin{array}{l}\text { ada 'exist', bangkit 'rise', bangun 'get up', datang } \\
\text { 'come', diam 'remain', duduk 'sit', gagal 'fail', } \\
\text { gugur 'die', habis 'finish up', hadir 'present', } \\
\text { hidup 'alive', hilang 'get lot', hinggap 'perch', } \\
\text { jatuh 'fall down', karam "sink', kasih 'like', } \\
\text { keluar 'get up', mati 'die', muncul 'appear', } \\
\text { mundur 'move back', naik 'rise', patah 'break', } \\
\text { pindah 'move', pulang 'go home', putus 'break', } \\
\text { rebah 'fall flat', roboh 'fall down', rugi 'lose', } \\
\text { sadar 'aware', sakit 'ill', sampai 'until', sayang 'be } \\
\text { affectionate', selesai 'be completed', sesak 'be } \\
\text { pressed', sesat 'get lost', surut 'ebb', tampak } \\
\text { 'appear', tampil 'appear', tanggal 'drop down', } \\
\text { tenggelam 'sink', terbang 'fly', terbit 'appear', } \\
\text { terjun 'fall down', tidur 'sleep', timbul 'pop up', } \\
\text { tinggal 'stay', tumbang 'fall down', tumbuh } \\
\text { 'grow up', turun 'go down', yakin 'confident' }\end{array}$ \\
\hline [-CAUSATIVE] & $\begin{array}{l}\text { benci 'hate', cinta 'love', hendak } \\
\text { 'intend', luput 'miss', mangkir } \\
\text { 'not come', mau 'want', mulai } \\
\text { 'start', punya 'have', singgah } \\
\text { 'stay', tahu 'know', turut 'join' }\end{array}$ & $\begin{array}{l}\text { pergi 'go', pingsan 'fall unconscious', semaput } \\
\text { 'be unconscious', tiba 'arrive', usai 'be finished' }\end{array}$ \\
\hline
\end{tabular}

The verbs ada 'exist' and bangkit 'rise up' in the list, for example, have the [-complement] feature. They can head a VP which can become the complement of Cs like in (19) and (20). 
(19a) Anna mengadakan pesta. Anna act- exist Cs party 'Anna held a party.'

(19b) [vcP - [v' meng- [csp Anna [Cs' -kan [vp pesta ada]]]]]

(20a) Ucapannya membangkitkan words his act-rise up Cs semangat para siswa. spirit pl. students

'His words raised the students' spirit.'

(20b) [ $\mathrm{vcP}_{\mathrm{cP}}-\left[\mathrm{vc}^{\prime}\right.$ meng- [csp ucapan [Cs' -kan [vp semangat para siswa bangkit]]]]]

In (19) ada 'exist' forms a VP [pesta ada] 'a party - to exsit', and the VP becomes the complement of Cs with Anna as specifier. In (20) bangkit 'rise up' forms a VP [semangat para siswa bangkit] 'the students' spirit - to rise up', and the VP becomes the complement of Cs with ucapannya 'his words' as the specifier.

Cs may also take a VP which has the feature of [+zero form of $\mathrm{Vc}$ ]. The verb baring and singkir can occur with the Vc ber- and meng-respectively, but they can also head a VP which becomes the complement of Cs. Study the following sentences. 'They lay down the child on the grass.'
$\left[\mathrm{vcP}-\left[\mathrm{vc}^{\prime}\right.\right.$ meng- [csp mereka [cs'-kan [vp anak itu baring di rumput]]]]]

(23) Prajurit-prajurit itu menyingkir. soldier soldier the act-run 'The soldier ran away.'

(24a) Mereka menyingkirkan prajuritthey act-run Cs soldier soldier the prajurit itu.

'They sent the soldiers away.'

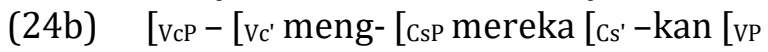
prajurit-prajurit itu singkir]]]]]

In (21) the sentence contains a VcP [anak itu berbaring di rumput], and in (22), the complement of Cs is the VP [anak itu baring di rumput] 'the child - to lie on the grass' and the specifier is mereka 'they'. In (23) the sentence contains a VcP [prajurit-prajurit itu menyingkir] 'the soldiers ran away', and in (24) the complement of Cs is the VP [prajuritprajurit itu singkir] 'the soldiers - to run away' and the specifier is mereka 'they'.

The ability of Cs to take a VP as its complement is not limited to a VP which has the feature [-complement]. A verb which sselect a PP as its complement may also head a VP which becomes the complement of Cs. Study the following sentences.

(25a) Saya mengingatkan Joko akan tugasnya.

I act-remember-Cs Joko of task his 'I reminded Joko his tasks.'

(25b) [ $\mathrm{vcP}^{-}$[ $\mathrm{vc}^{\prime}$ meng- [csp saya [cs' -kan [vp Joko ingat pada tugasnya]]]]]

(26a) Linda mengenalkan saya pada

Linda act-know-Cs I to teman-nya.

friend his

'Linda introduced me to her friend.'

(26b) $\left[\mathrm{vcP}_{\mathrm{c}}-\left[\mathrm{vc}^{\prime}\right.\right.$ meng- $\left[\mathrm{csp}\right.$ Linda $\left[\mathrm{Cs}^{\prime}-\mathrm{kan}[\mathrm{vP}\right.$ saya kenal pada temannya]]]]]

The complement of Cs in (25) is the VP [Joko ingat pada tugasnya] 'Joko - to remember his tasks'. In the VP, pada tugasnya 'of his tasks' is the complement of ingat 'remember', and Joko is the specifier. In (26), the complement of Cs is the VP [saya kenal pada temannya] 'I - to know at his friend'. Pada temannya 'at his friend' is the complement of kenal 'know', and saya 'I' is the specifier. Both ingat 'remember' and kenal 'know' take a PP as their complement. Other verbs which s-select a PP as their complement and which can head a VP as the complement of Cs are aju 'propose', alih 'to change', sanding 'sit close to, ingat 'remember', dan tunduk 'to obey'.

A verb which s-selects an NP as its complement can also head a VP which becomes the complement of Cs. In (27) and (28) below the heads of the VPs are the verbs tembak 'to shoot' and pukul 'to hit', which both can take an NP as their complement.

$$
\begin{aligned}
& \text { Ia menembakkan pistolnya ke } \\
& \text { he act-shoot-Cs pistol his to } \\
& \text { udara. } \\
& \text { air }
\end{aligned}
$$




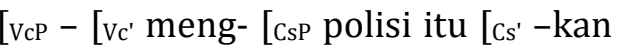
[vp pistolnya tembak ke udara]]]]]

(28a) Ia memukulkan patungitu ke he act-strike-Cs statue the to kepala perampok itu. head robber the

'He struck the statue to the robber's head.'

(28b) [ $\mathrm{vcP}^{-}-\left[\mathrm{vc}^{\prime}\right.$ meng- [csp ia [ $\mathrm{Cs}^{\prime}-\mathrm{kan}$ [vp patung itu pukul kepala perampok itu]]]]]

The complement of Cs in (27) is the VP [pistolnya tembak ke udara] 'the gun - to shoot -at the air', and the complement of Vs in (28) is the VP [patung itu pukul kepala perampok itu] 'the statue - to strike - to the robber's head'.

To become the head of a VP which can function as the complement of Cs, the verbs tembak 'shoot' and pukul 'strike' have to undergo a semantic process, call it a semantic reconstruction. The verbs tembak 'to shoot' and pukul 'to strike' s-select an NP which has the [+human] feature as its specifier and an NP as its complement. In (27) the specifier of tembak 'shoot' and pukul 'to strike' are the NPs pistolnya 'his pistol' and patung itu 'the statue' which have a [-human] feature. Such NPs usually occur as the complement of a PP which become an adjunct to show an instrument like dengan pistolnya 'with his gun' and dengan patung itu 'with the statue'. Furthermore, the NPs which usually becomes a complement functions an adjunct introduced with ke to', namely ke udara 'to the air' and ke kepala perampok itu 'to the robber's head'.

Similar to tembak 'to shoot' and pukul 'to strike', the verbs gores 'to scratch', hantam 'to hit', todong 'to aim a gun', and tusuk 'to stab' can also head a VP which becomes the complement of Cs. The verbs should also undergo a semantic reconstruction to occur in the position.

The verb minum 'to drink' and sewa 'to rent' can also become the head of a VP which becomes the complement of Cs. Study (29) and (30) below.

(29a) Ibu meminumkan obat itu pada mom act-drink-Cs drug the to

Diana.

Diana

'Mom made Diana drink the medicine.'

(29b) [ ${ }_{\mathrm{vcP}}-{ }_{\mathrm{vc}}$ meng- [csp ibu [cs' -kan [vp Diana minum obat itu]]1]]

(30a) Pak Hardi menyewakan

rumahnya pada orang

asing.

Mr. Hardi act-rent-Cs house

the to person foreign

'Mr. Hardi rent out his house to a foreigner.'

(30b) [ $\mathrm{v}_{\mathrm{cP}}-\left[\mathrm{vc}^{\prime}\right.$ meng- [csp pak Hardi [ $\mathrm{cs}^{\prime}$-kan [vp orang asing sewa rumah itu]]]]]

The complement of Cs in (29) is the VP [Diana minum obat itu] 'Diana - to drink - the medicine', and the complement of Cs in (30) is the VP [orang asing sewa rumah itu] 'the foreginer - rent - the house'. The VP in (29) and (30) does not undergo a semantic reconstruction, but the NP Diana in (29) and the NP orang asing itu 'the foreigner' in (30) do not receive a syntactic case in their base position and they cannot move to any place where they can be assigned a case. They can get a nominative case when they occupy the specifier position of Vc. The position is occupied by ibu in (29) and pak Hardi 'Mr. Hardi' in (30), which are the specifiers of -kan. The preposition pada 'at' is, therefore, inserted to save the NPs, and then the new PPs become adjuncts. This process may be called an NP lowering.

CsP as a complement of Vc can also take $\mathrm{AP}$ as its complement. The complement of $\mathrm{Cs}$ in (31) and (32) is an AP.

(31a) Mereka meremehkan tim lainnya. they act-worthless-Cs team other 'They underestimate the other teams.'

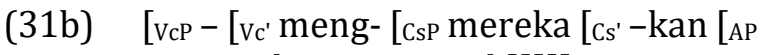
tim-tim lainnya remeh]]]]]

Pemerintah menghijaukan

government act-green-Cs

daerah kering itu.

area dry the

'The government reforest the dry area.'

(32b) [ $\mathrm{vcP}^{-}\left[\mathrm{vc}^{\prime}\right.$ meng- $\left[\mathrm{csP}\right.$ pemerintah [ $\mathrm{Cs}^{\prime}-$ kan [AP daerah kering itu hijau]]]]] 
The complement of Cs in (31) is the AP [timtim lainnya remeh] 'other tem - worthless'. In the AP, remeh 'worthless' is the head, and timtim lainnya 'the other teams' is the specifier. In (31), the complement of Cs is the AP [daerah kering itu hijau] 'the dry area - green'. In the AP in (32), hijau 'green' is the head, and daerah kering itu 'the dry area' is the specifier.

Cs may also take an NP as its complement. In (33) and (34) below, the complement of Cs is an NP.

(33a) Pak Ahmad menguangkan ceknya. Mr. Ahmad act-money-Cs check his 'Mr. Ahmad cashed his check.'

(33b) [vcP - [ $\mathrm{vc}^{\prime}$ meng- ${ }_{\mathrm{Cs}}$ mereka [cs' $-\mathrm{kan}[\mathrm{NP}$ ceknya uang]]]]]

(34a) Bu Martamenyekolahkan

Ms. Marta act-school-Cs

anaknya di Tarakanita.

kid her in Tarakanita

'Ms. Marta sent her kid to study in Tarakanita.'

(34b) [vcP - [v' meng- [csp mereka [cs' - kan [NP anaknya sekolah di Tarakanita]]]]]

The complement of Cs in (33) is the NP [ceknya uang] 'his check - money', and the complement of Cs in (34) is the NP [anaknya sekolah di Tarakanita] 'her kid - school in Tarakanita'. In (33) the head of the NP is the noun uang 'money', and ceknya 'his check' is the specifier. In (34), sekolah 'school' is the head of the NP, and PP di Tarakanita 'in Tarakanita' is an adjunct, and anaknya 'her kid is the specifier.

Another category which can become the complement of Cs is a PP. Study sentence (35) and (36) below.

(35a) Mereka mengekemukakan

they act - to front - Cs

pendapatnya.

opinion his

'They expressed his opinion.'

(3b) $\quad\left[\mathrm{vcP}-\left[\mathrm{Vc}^{\prime}\right.\right.$ meng- $\left[\mathrm{csp}\right.$ mereka $\left[\mathrm{cs}^{\prime}-\mathrm{kan}[\mathrm{PP}\right.$ pendapatnya ke muka]]1]]

(36a) Polisi itu mengeluarkan

policeman the act-to-out-Cs

pistolnya.

pistol his

'The policeman took out his pistol.'

(36b) [ $\mathrm{vcP}^{-}$[ $\mathrm{vc}^{\prime}$ meng- [csp polisi itu [ $\mathrm{Cs}^{\prime}-\mathrm{kan}$
[PP pistolnya keluar]]]]]

The complement of $\mathrm{Cs}$ in (35) is the PP [pendapatnya ke muka] 'his opinion - to front'. In the PP, ke 'to' is the head, muka 'front' is the complement of ke 'to', and pendapatnya 'his opinion' is the specifier. In (36), the complement of Cs is the PP [pistolnya keluar] 'his pistol - to - out', in which ke 'to' is the head, the NP luar 'out' is the complement, and the NP pistolnya 'his pistol' is the specifier. Ke luar 'to - out' as a head - complement construction is often written as a word keluar 'go out' and is considered as a verb.

The last category which can become the complement of Cs is a NumP. The complement of Cs in (37) is the NumP [beberapa kelompok kecil itu satu].

Ia menyatukankelompok-kelompok
he act-one-Cs group group
kecil itu.
small the

'He united the small groups.'

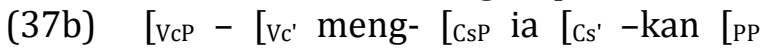
beberapa kelompok kecil itu satu]]]]]

In the NumP, the head is satu 'one', the specifier is the NP kelompok-kelompok kecil itu 'the small group'.

Except a preposition, all the types of the head of the phrase which become the complement of Cs has the characteristic of [complement]. The verbs habis 'finish' and roboh 'fall down', the adjectives remeh 'worthless' and hijau 'green', and the nouns uang 'money' and sekolah 'school' have the feature [-complement].

As has been said earlier, the core meaning of Cs is 'causative'. When a CsP becomes the complement of a $\mathrm{Vc}$, the construction means that the person or thing as expressed by the specifier of Cs does something so that the action or state as expressed by the phrase which becomes the complement of Cs happens. Such a meaning appears in (38) - (43).

(38a) Ia menggagalkan perampokan itu. he act-fail Cs robbery the 'He failed the robbery.'

(38b) [ $\mathrm{vcP}^{-}{ }_{\mathrm{vc}}$ meng- $\left[\mathrm{csP}\right.$ ia $\left[\mathrm{cs}^{\prime}-\mathrm{kan}[\mathrm{vP}\right.$ 
perampokan itu gagal]]]]]

$\begin{array}{ll}\text { Ia menundukkan } & \text { semua } \\ \text { he act-surrender Cs } & \text { all }\end{array}$

penantangnya.

challenger his

'He conquered all his challengers.'

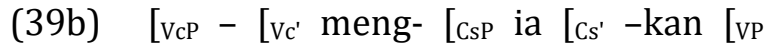
semua penantangnya tunduk]]]]]

(40a) Ahmad menyewakan sepeda Ahmad act-rent Cs bicycle pada turis.

to tourist

'Ahmad rent out bicycles to tourists.'

(40b) [ vcP - [vc' meng- [csp Ahmad [cs' -kan [vp turis sewa sepeda]]]]]

(41a) Pemerintah membekukan

government act-freeze Cs

hubunganya dengan Afganistan.

relation its with Afganistan

'The government froze its relation with Afganistan.'

(41b) [vcP - [vc' meng- [ $\mathrm{csp}$ pemerintah $\left[\mathrm{Cs}^{\prime}-\right.$ kan [AP hubungannya dengan Afganistan beku]]]]]

(42a) Ia menjadwalkan pertemuan itu he act- schedule Cs meeting the pada hari Rabu.

at day Wednesday

'He scheduled the meeting on Wednesday.'

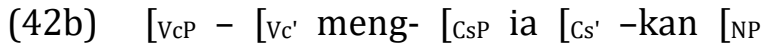
pertemuan itu jadwal pada hari Rabu]]]]]

(43a) Ia menyatukan kedua paragraf itu he act-one Cs two paragraphs the 'He combined the two paragraphs.'

(43b) [vcP - [ $\mathrm{vc}^{\prime}$ meng- [ $\mathrm{csp}$ ia [ $\mathrm{cs}^{\prime}-\mathrm{kan}$ [ $\mathrm{PP}$ kedua paragraf itu satu]]]]]

In all the sentences, Cs has a causative meaning.

\section{Complement of Additive per-}

A CsP may also become the complement of per-, call it additive or Adt which also functions as an inflection. In (44) and (45) below, the CsP becomes the complement of Adt.

(44a) Mereka mempermasalahkan they act- Adt problem Cs pertemuan itu. meeting the 'They questioned the meeting.' (44b) [ $\mathrm{vcP}^{-}$[ $\mathrm{vc}^{\prime}$ meng- [AdtP mereka [Adt' per[csP mereka [Cs' - kan [NP pertemuan itu masalah]]]]]]]

(45a) Ia mempertemukan kedua he act- Adt meet Cs two pemuda itu. youngsters the

'He arranged the meeting of the two youngsters.'

(45b) [ $\mathrm{vcP}^{-}-\mathrm{Vvc}^{\prime}$ meng- [AdtP ia [Adt' per- $[\mathrm{CsP}$ ia [cs' -kan [vp kedua pemuda itu temu]]]]]]]

In (44) Cs has the NP [pertemuan itu masalah] 'the meeting - problem' as its complement. In (45) Cs has the VP [kedua pemuda itu temu] 'the two youngsters - to meet' as the complement.

Cs in a CsP which becomes the complement of Adt also has a causative meaning. In (44) they did something so that the meeting became a problem, and in (45) he did something so that the two young people met.

\section{Complement of Verb}

Some verbs which takes a PP as their complement may also take a CsP as their complement. The verbs lupa in (46) and ingin in (47) take a CsP as their complement.

(46a) Rudi melupakan tugasnya. Rudi act-forget Cs task his 'Rudi forgot his tasks on purpose.'

(46b) [vcP - [ $\mathrm{vc}^{\prime}$ meng- [vp Rudi [v' lupa [csp Rudi -kan tugasnya]]]]]

(47a) Mereka menginginkan uangnya. they act-want-Cs money his 'They want his money.'

(47b) [ $\mathrm{vcP}_{\mathrm{c}}-\left[\mathrm{vc}^{\prime}\right.$ meng- [vp mereka [v' ingin [csP mereka -kan uangnya]]]]]

The compelement of lupa 'forget' in (46) is the CsP [Rudi -kan tugasnya] 'Rudi -Cs - his task'. Cs in the phrase takes the NP tugasnya 'his task' as the complement, and the NP Rudi as the specifier. In (47), the verb ingin 'want' takes the CsP [mereka -kan uangnya] 'they Cs his money' as the complement. In the CsP, the NP uangnya 'his money' is the complement of $\mathrm{Cs}$, and the NP mereka 'they' is the specifier. 
The presence of Rudi as the specifier of Cs in (46) and mereka 'they' as specifier of Cs in (47) is justifiable because Cs can take a specifier. Just like when a CsP becomes the complement of a Vc, Cs can also take a specifier when it becomes the complement of a verb. The NPs are then deleted in the same as an NP which becomes the specifier of a VP like in (48).

(48a) Saya ingin membeli bunga. I want act-buy flower 'I want to buy flowers.'

(48b) [ $\mathrm{vcP}_{\mathrm{cP}}-\left[\mathrm{v}^{\prime}\right.$ meng- [vp saya [v' ingin [ $\mathrm{vcP}_{\mathrm{cP}}-$ [v' meng- [vp saya beli bunga]]]]]]]

In (48) both ingin 'want' and beli 'to buy' have the NP saya 'I' as the specifier, but the specifier of beli is later deleted because it is the same as the specifier of ingin 'want'. Similarly, Rudi in [Rudi -kan tugasnya] 'Rudi Cs his task' and mereka 'they' in [mereka -kan uangnya] 'they Cs his money' are also deleted because they are the same as the specifier of lupa 'forget' and ingin 'his money' respectively.

The verbs dengar and ajar which takes an $\mathrm{NP}$ as their complement may also take a CsP as its complement. The verbs dengar 'hear' in (49) and ajar 'study' in (50) take a CsP as its complement.

(49a) Saya mendengarkan musik. I act-hear Cs music 'I listen to music.'

(49b) [vcP - [ $\mathrm{vc}^{\prime}$ meng- [vp saya [ $\mathrm{v}^{\prime}$ dengar [ $\mathrm{CsP}^{\mathrm{P}}$ saya -kan musik]]]]]

(50a) Ia mengajarkan teori itu he act-teach Cs theory the pada mahasiswa semester 5 . to student semester 5 'I taught the theory to the students of semester 5.'

(50b) [vcP - [vc' meng- [vp ia [ $\mathrm{v}^{\prime}\left[\mathrm{v}^{\prime}\right.$ ajar [csp ia kan teori itu] pada mahasiswa semester 5]]]]]

The complement of dengar 'to hear' in (49) is the CsP [saya -kan musik] 'I -kan music', and the complement of ajar 'to teach' in (50) is the CsP [ia -kan teori itu] 'he - kan the theory'. If a verb s-selects both an NP and a CsP as its complement, the NP which becomes the complement of the verb is the same as the NP which becomes the complement of Cs. Compare (49) and (50) with (51) and (52) respectively.

(51a) Saya mendengar musik. I act-hear music 'I heard music.'

(51b) [ $\mathrm{vcP}_{\mathrm{cP}}-\left[\mathrm{V}_{\mathrm{c}}\right.$ meng- [vp saya dengar musik]]]

(52a) Ia mengajar teori itu pada he act teach theory the to mahasiswa semester 5 . student semester 5 'He taught the theory to the student of semester 5.'

(52b) [vcP - [vc' meng- [vp saya ajar teori itu pada mahasiswa semester 5]]]

The complement of dengar 'hear' in (51) and the complement of ajar 'teach' in (52) are musik 'music' and teori itu 'the theory' respectively. The complement of Cs in (49) is also musik 'music', and the complement of Cs in (50) is also the teori itu 'the theory'.

The choice of a CsP as a complement instead of a PP or an NP adds a new meaning to the meaning of the verb. Study sentences (53) and (54) below.

(53a) Anna lupa pada beberapa teman Anna forget at some friends lamannya. old her 'Anna forgets some of her old friends.'

(53b) Anna melupakan beberapa teman Anna act-forget-Cs some lamanya. old her 'Anna forgets some of her old friends.' (54a) Rita mendengar musik. Rita act-hear music 'Rita heard music.'

The forms lupa 'forget' and mendengar 'hear', which have a PP and an NP respectively as the verb complement, show an unintentional action, whereas the forms melupakan 'forget' and mendengarkan 'listen', which have a CsP as the verb complement show an intentional 
action. The 'intention' meaning appeas because the forms also carry a causative meaning.

\section{Adjunct of Verb}

A CsP may also become an adjunct of a verb which s-selects an NP as its complement. The verb beli 'to buy' and the verb baca 'to read', for example, take an NP as their complement. Study (55) and and (56) below.

(55a) Rita membeli baju.

(55b) [vcP - [ $\mathrm{vc}^{\prime}$ meng- [vp Rita beli baju]]] act - Rita buy dress

'Rita bought a dress.'

(56a) Ibu membaca cerita.

(56b) $\left[\mathrm{vcp}-\left[\mathrm{Vc}^{\prime}\right.\right.$ meng- [vp ibu baca cerita]]]

act- Mom read story

'Mom read a story.'

The complement of beli 'to buy' in (55) is baju 'a shirt', and the complement of baca 'to read' in (56) is cerita 'a story'. A CsP can be added to the VP in (55) and (56) as an adjunct to form (57) and (58) respectively.

(57a) Rita membelikan Hardi baju.

(57b) [vcP- $\left[\mathrm{vc}^{\prime}\right.$ meng- $\left[\mathrm{vp}\right.$ Rita $\left[\mathrm{v}^{\prime}\left[\mathrm{v}^{\prime}\right.\right.$ beli baju] [csp Rita-kan Hardi]]]]] act- Rita buy dress Rita Cs Hardi

'Rita bought Hardi a shirt.'

(58a) Ibu membacakan Joko cerita.

(58b) $\left[\mathrm{vcP}-\left[\mathrm{vc}^{\prime} \quad\right.\right.$ meng- $\left[\mathrm{vp}\right.$ ibu $\left[\mathrm{v}^{\prime} \quad\left[\mathrm{v}^{\prime}\right.\right.$ baca cerita] [csp ibu -kan Joko]]]]] act- Mom read story Mom Cs Joko

'Mom read Joko a story'

The Csp [Rita -kan Hardi] is an adjunct of beli 'buy' in (57), and the CsP [ibu -kan Joko] is the an adjunct of baca 'read' in (58).

A CsP which becomes an adjunct of a verb which s-selects an NP as its complement shows a benefactive meaning. It shows that the agent does the action for the person as indicated by the complement of Cs. In (57) Rita bought a shirt for Hardi, and in (58) Mom read a story for Joko.

As has been discussed above, the general meaning of the suffix -kan or Cs is 'causative'. The meaning may vary slightly in the context. It can show a pure causative meaning, an intentional meaning, or a benefactive meaning. It shows a pure causative meaning when a CsP becomes the complement of a Vc or Adt, an intentional meaning when a CsP becomes a complement of a verb, and a benefactive meaning when it becomes an adjunct of a verb.

The occurrence of a CsP as a complement of a Vc, Adt, or verb or the adjunct of a verb is determined by the semantic feature of the verb or the lexical item which becomes the head of the phrase with which Cs is to be attached. A CsP becomes a complement of a Vc and Adt if the verb or lexical item has the feature of [complement] like habis 'finish', roboh 'fall dwon', jatuh 'fall down', kecil 'small', uang 'money', and satu 'one', (ii) if the verb has the feature of $[+\mathrm{PP} /$ complement $]$ like ingat 'remember' and lupa 'forget', or (iii) if the verb can undergo a semantic reconstruction like tembak and tusuk or an NP lowering like minum 'drink' and sewa 'rent'. A CsP becomes the complement of a verb if the verb can take a PP or an NP as a complement. The verbs which can take a CsP as their complement are only lupa 'forget', ingin 'want', dengar 'hear', and lihat 'see'. Finally, a CsP can become an adjunct of a verb if the verb can take an NP as its complement. The distribution of a CsP can summarized in Table 2. 
Table 2

The Functions of the Casative Cs

\begin{tabular}{|c|c|c|c|}
\hline No. & Functions & Syntactic Features & Examples \\
\hline \multirow[t]{5}{*}{1.} & \multirow[t]{5}{*}{$\begin{array}{l}\text { Complement } \\
\text { of Verb }\end{array}$} & $\begin{array}{l}\text { +Verb } \\
\text {-COMPLEMENT }\end{array}$ & $\begin{array}{l}\text { bangkit 'rise up', datang 'come', tidur sleep', habis } \\
\text { 'finish, roboh fall down', jalan 'walk', alir 'flow' }\end{array}$ \\
\hline & & $\begin{array}{l}\text { +Verb } \\
+ \text { PP/Complement }\end{array}$ & $\begin{array}{l}\text { aju 'put forward', alih 'change', sanding 'sit/stand } \\
\text { close to' }\end{array}$ \\
\hline & & $\begin{array}{l}\text { +Verb } \\
+\mathrm{NP} / \text { Complement } \\
+ \text { Semantic } \\
\text { Reconstruction }\end{array}$ & $\begin{array}{l}\text { tembak 'shoot', tulis 'write', gores 'scratch', pukul } \\
\text { 'hit' }\end{array}$ \\
\hline & & $\begin{array}{l}+ \text { Verb } \\
+ \text { NP/ } \\
\text { Complement } \\
\text { +Semantic } \\
\text { Reconstruction }\end{array}$ & $\begin{array}{l}\text { minum 'drink', ajar 'study/learn', sewa 'rent', pinjam } \\
\text { 'borrow' }\end{array}$ \\
\hline & & -Verb & $\begin{array}{l}\text { sakit 'sick', lebar 'wide', buku book' rumah 'house', } \\
\text { satu 'one', ke tengah 'to the middle', ke muka 'to the } \\
\text { front' }\end{array}$ \\
\hline \multirow[t]{2}{*}{2.} & \multirow[t]{2}{*}{$\begin{array}{l}\text { Complement } \\
\text { of Vc }\end{array}$} & $\begin{array}{l}\text { +Verb } \\
\text { +NP/Complement } \\
\text { +NP lowering }\end{array}$ & dengar 'hear' \\
\hline & & $\begin{array}{l}\text { +Verba } \\
\text { +FP/Complement }\end{array}$ & lupa 'forget', perlu 'need', ingin 'want' \\
\hline \multirow[t]{2}{*}{3.} & \multirow[t]{2}{*}{$\begin{array}{l}\text { Adjunct of } \\
\text { Verb }\end{array}$} & $\begin{array}{l}\text { +Verb } \\
+\mathrm{PP} / \text { Complement }\end{array}$ & percaya 'believe' \\
\hline & & $\begin{array}{l}\text { +Verb } \\
+\mathrm{NP} / \text { Complement }\end{array}$ & $\begin{array}{l}\text { ambil 'take', beli 'buy', buat 'make', baca 'read', } \\
\text { masak 'cook', bawa 'bring', buka 'open' }\end{array}$ \\
\hline
\end{tabular}

From the table, it can be seen that CsP has three functions namely as the complement of $\mathrm{V}$, a complement of Vc, and the adjunct of $\mathrm{V}$. The three different functions explain the three different meanings which occur with a -kan verb in Indonesian.

\section{Conclusion}

The treatment of the Indonesian affix -kan as an affix which head a phrase (CsP) can solve the problems which appear in the discussion of the affix as a derivation which functions to form new verbs. The theory can explain the different meanings which the affix seems to show. The different meanings appear because of the different syntactic function which the affix performs. Furthermore, the theory can also explain the syntactic similarity which pairs of Indonesian sentences show.
For the discussion of the -kan suffix to be useful for practical purposes, further studies need to be conducted. A study on the comparison Indonesian sentences with the different uses of the suffix and their equvailants in English will be useful for learning and teaching purposes, and a study on the translation of Indonesian sentences with kan may provide helps to translators.

\section{References}

Chomsky, N. (1981). Lectures on Government and Binding: The Pisa Lectures. Dordrecht: Foris Publications.

Chomsky, N. (1995). The Minimalist Program. Cambridge: The MIT Press. 
Chung, S. (2008). Indonesian clause structure from an Austronesian perspective. Lingua 118, 1554-82.

doi:https://doi.org/10.1016/j.lingua.200 7.08.002

Cole, P., Hermon, G., \& Yanti. (2008). Voice in Malay/Indonesian. Lingua 118, 1500-53.

Dwijatmoko, B. B. (2002). English Syntax. Yogyakarta: Sanata Dharma Press.

Dwijatmoko, B. B. (2020). Sintaksis Verba Bahasa Indonesia. Yogyakarta: Sanata Dharma University Press.

Haegeman, L. (1991). Introduction to Government and Binding. Cambridge, M.A.: Basil Blackwell, Inc.

Haegeman, L., \& Gueron., J. (1999). English Grammar: a generative perspctive. Malden: Blackwell Publishing. doi:https://doi.org/10.1016/j.lingua.200 7.08.008

Kaswanti Purwo, B. (1995). The two prototypes of ditransitive verbs: The Indonesian evidence. , 77-101. In W. Abraham, T. Givon, \& S. A. Thompson, Discourse, Grammar and Typology (pp. 77-101). Amsterdam: John Benjamins. doi: https://doi.org/10.1075/slcs.27.08kas

Kaswanti Purwo, B. (1997). The Direct Object in Bi-transitive Clauses in Indonesian. In T. Givon, Grammatical Relations: A Functionalist Perspective (pp. 233-52.). Amsterdam: John Benjamins. doi:https://doi.org/10.1075/tsl.35.06pur

Moeliono, A. M., \& Darwjowidjojo, S. (1998). Tata Baku Bahasa Indonesia. Jakarta: Balai Pustaka.

Radford, A. (1988). Transformation Grammar: A First Course. Cambridge: Cambridge University Press.
Radford, A. (2004). Minimalist Syntax: Exploring the Strucure of English. Cambridge: Cambridge University Press.

Seuren, P. A. (2004). Chomsky's Minimalism. New York: Oxford University Press.

Sneddon, J. N. (1996). Indonesian: A Comprehensive Grammar. New York: Routledge.

Soh, H. L. (2010). Voice and Aspect: Some Notes from Malay. Proceedings of the Workshop on Indonesian-type Voice System, 25 - 35. (pp. 25 - 35). Tokyo: University of Foreign Studies Asian and African Institute for Language and Culture.

Soh, H. L., \& Nomoto, H. (2009). Progressive Aspect, the Verbal Prefix meN-, and Stative Sentences in Malay. Oceanic Linguistics 48(1), 148-171. doi:https://doi.org/10.1007/s10831010-9069-5

Soh, H. L., \& Nomoto, H. (2011). The Malay verbal prefix meN-and the unergative/unaccusative distinction. Journal of East Asian Linguistics 20: , 77106.

Son, M., \& Cole, P. (2008). An Event-Based Account of -kan Constructions in Standard Indonesian. Language 84, 120 160.

Travis, L. d. (2007). Bahasa Indonesia: A window on parameters. Lingua, 118, 1583-1602. doi:https://doi.org/10.1016/j.lingua.200 7.08.010

Zagona, K. (2002). The Syntax of Spanish. Cambridge: Cambridge University Press. 